\title{
NEWS OF THE SECTIONS
}

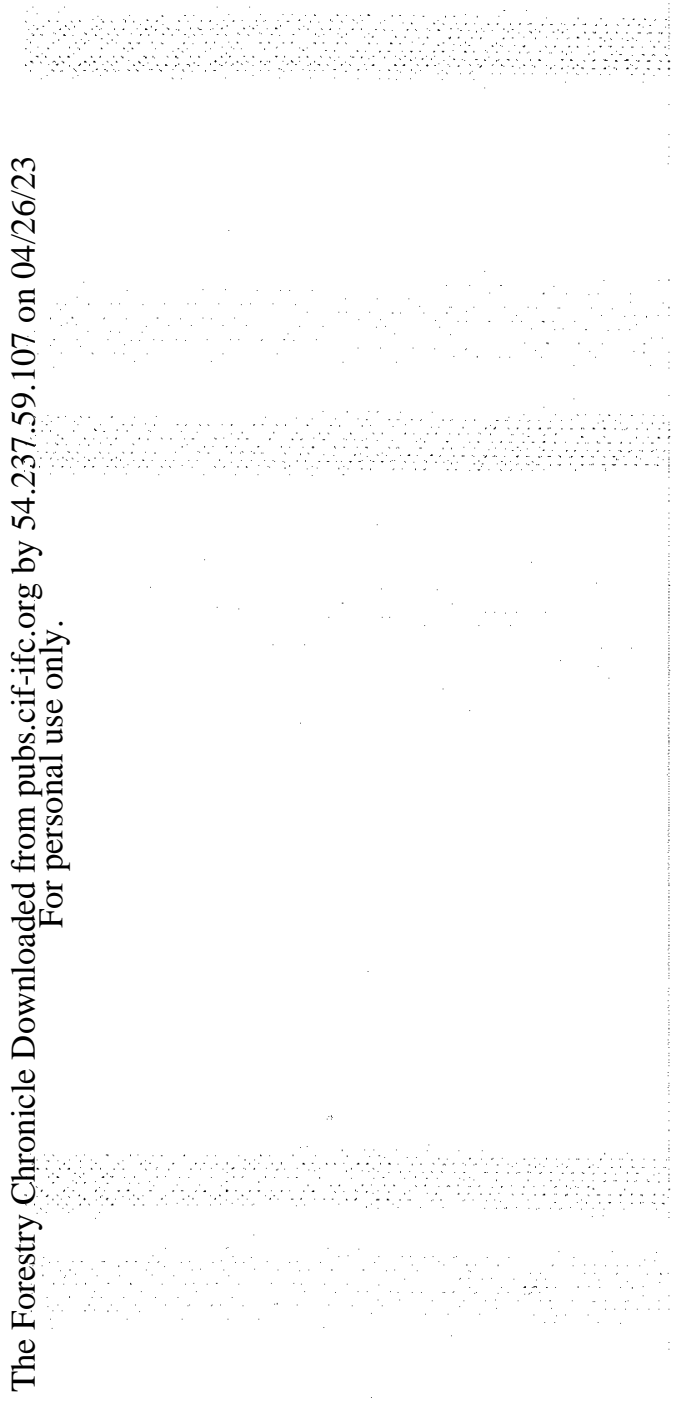

\section{NEWFOUNDLAND}

First and foremost your reporter must apologize to all who read this section for the absence of my report in the last issue. The report went forth but too late for inclusion in the September Chronicle. Blame it on the field season if you like.

The main activity since my last report was the holding of a highly successful field meeting (in late September) on the Bonavista Peninsula. Fifteen delegates attended the 2 day session obtaining in the process an understanding of the forestry problems in the area and the steps Crown authorities have taken and are taking to control and regulate cutting on unlicensed Crown lands. Other items of forestry interest were the Managed Woodlot of the Federal Forestry Branch and several Provincial Forest plantations.

On the lighter side the delegates were able to visit many points of historic interest, among them the landfall of John Cabot at Cape Bonavista.

All who were fortunate enough to attend this meeting felt that it had been an unqualified success.

With reference to meetings our Annual Meeting will be held in early December in Grand Falls. More about this in the March Issue.

Sad to say I must again report the loss, permanent and otherwise, of some of our members. Those who I believe have left us for good are Sandy Macpherson, Bob Ellis, Gary Saunders, and Tom Foulkes. As far as we know all of the above are returning to colleges for post-grad work. Also doing likewise except we expect him back is Dave Bryant.

New members who have helped offset our losses are Hubert Baker, Temple Baird and Bert Frampton all of the A.N.D. Company as well as Al Brennan (U.N.B. '60) with the Provincial Forestry Division, Dept. Mines, Agriculture \& Resources.

Congratulations to Ed Ralph on his appointment to the position of Chief Forester with the aforementioned Dept. of Mines, Agriculture \& Resources. Other members who have stepped into new positions recently are Nels Williams now Assistant Superintendent, Millertown Division, A.N.D. Company and Ford Budgell, holding a similar position in the Company's Badger Division.

W. A. Dickson

\section{Nova Scotia}

At the first general meeting of the Canadian Forestry Association of Nova Scotia in Halifax, October 31st, R. L. Seaborne, of Liverpool, was-re-elected president, R. R. Murray, of Truro, was elected vice-president and F. L. Gray, of Liverpool, secretary. At this meeting it was agreed that this Association would continue to sponsor Tree Farms and, with the assistance of the Nova Scotia Section of the C.I.F., provide Tree Farm inspection and certification. It was also decided that the Association would encourage and support the organization and activity of 4-H Forestry Clubs in Nova Scotia.

Nova Scotia's first Tree Farm was certified at a roadside ceremony September 14th. The certificate is for Bowaters Mersey Paper Company's Herring Cove Lake Tree Farm of approximately 17,500 acres near Liverpool. 
R. L. Seaborne retired from the position of Woodlands Manager of Mersey Paper Company Limited in 1958 and he is now Director of the Parks Division of the Nova Scotia Department of Lands and Forests.

Hollis T. Routledge, formerly District Forester for the Department of Lands and Forests, has accepted the position as Divisional Forester with Nova Scotia Pulp Limited. Hollis is located in Port Hawkesbury on Cape Breton Island.

Members of the Nova Scotia Section who attended the Annual C.I.F. Meeting held in Quebec City reported an excellent Meeting and wish to extend their appreciation to the Quebec Section and to the Corporation of Forestry Engineers of the Province of Quebec.

The annual meeting of the Nova Scotia Section C.I.F. is to be held February 2nd and 3rd at Truro. Subjects to be discussed include Silviculture, Forest Taxation, Land Use and Wild Life, based on papers prepared by Section committees.

R. S. JoHNSON

\section{Maritime}

Dr. J. M. Gibson, Dean of Forestry, University of New Brunswick received an Honorary Doctorate in Forestry at the Convocation marking the 50th Anniversary of Forestry teaching at Laval University.

W. R. Duffie, who entered provincial politics in this year's elections was returned as member for Sunbury County. He was subsequently named Ministerdesignate of Youth in the Provincial Cabinet.

Dr. R. M. Belyea has taken up his appointment as Officer-in-Charge of the Forest Biology Laboratory, Canada Department of Agriculture, Fredericton. Dr. Belyea was previously head of the Sault Ste. Marie Forest Insect Laboratory.

Dr. R. E. Balch, who retired recently as Officer-in-Charge of the Dominion Forest Biology Laboratory in Fredericton is continuing his research project on the Balsam Wooly Aphid.

W. W. McCormack retires as Deputy Minister of the Department of Lands and Mines in December.

G. L. Stone, UNB ' 60 , is assisting Dr. A. G. Davidson at the Forest Biology Laboratory, Fredericton.

R. L. Bishop of Fredericton has been appointed Acting Executive Assistant to the Minister of Lands and Mines of New Brunswick.

G. L. Miller and L. S. Webb were made Life Members of the Association of Registered Foresters of New Brunswick this year. The Association has an active membership of ninety-eight of which number the majority are also members of the Maritime Section.

R. C. Parent was recently appointed Director of the Research Laboratory, Canada Department of Agriculture, Charlottetown, P.E.I.

Gordon L. Baskerville, attached to the Maritimes District Office of the Federal Forestry Branch, is now taking graduate studies at the Yale Forestry School, leading to a doctorate.

Dr. S. L. Pringle has returned to the University of New Brunswick after 
spending several months in Uganda, Tanganyika and Kenya. Dr. Pringle carried out a research project for the Food and Agriculture Organization of the United Nations on the forest products industry potential in those countries. He has lectured to various University groups on the subject and on social conditions in East Africa, since his return.

John G. Burchill was recently elected President of the Associated Alumni of the University of New Brunswick. Besides supervising the family lumber business in South Nelson, Mr. Burchill is Chairman of the Maritime Lumber Bureau, Chairman of the Forest Products Laboratories Advisory Committee on Sawmilling and a member of the main Advisory Committee, a member of the Canadian Wood Development Council and a leader in a number of other national, provincial and local organizations.

Professor E. C. Mobbs, Head of the Forestry School at the University of North Wales, Bangor, spent five days at the University of New Brunswick while returning from the World Forestry Congress in Seattle, Washington. He visited the Acadia Forest Experiment Station and gave lectures at the University on forestry in Great Britain, France and the Himalayas.

The Woodlands Section of the C.P.P.A. held a logging convention, August 15-17, in Fredericton with headquarters at the University of New Brunswick. Tours of the Acadia Forest Experiment Station were arranged under the guidance of Messrs. G. C. Cunningham, E. L. Hughes and B. C. Wile.

The 24th Annual Meeting of the Maritime Section originally scheduled for September at the Green River Research Station was postponed on account of the high Forest Fire Danger Index. Many members were either actually fighting fires or standing by in case of an outbreak. The meeting was finally held in Fredericton October 13th and 14th, at such short notice that there was not sufficient time for any members to prepare technical papers of any length. Four short talks were proposed and presented on the following subjects: Dr. J. M. Gibson -The Fifth World Forestry Congress at Seattle; D. A. Wolstenholme-The Fire Situation in N.B. 1960; D. G. Mott - The Spruce Budworm Situation in N.B. 1960 and Dr. S. L. Pringle-Forestry in East Africa.

Professor A. D. Nutting, Director, School of Forestry, University of Maine, was the guest speaker at the annual dinner. Professor Nutting served as Forest Commissioner for the State of Maine for a number of years and recently took up his present position at the University. His topic was the Northeastern Forest Fire Control Commission-Why and how it was organized and the function of the Commission in the Northeastern United States.

\section{Business Meeting}

The highlights of the reports by the Chairman, Secretary and Treasurer were that:

1. The Section membership stands at a record high of 157.

2. The Section has set up a Student Loan Fund for University of New Brunswick and Maritime Forest Ranger School Students.

3. The meeting endorsed the new proposed by-laws for the Section and a letter ballot will be held shortly. 
Reports of Section Representatives were given. Representative to the Association of Registered Professional Foresters of New Brunswick, J. Ian MacDonald, reported that a new scaling manual was put out by the Department of Lands and Mines, and that the Association favoured the new coordinate system of land surveys. The Association is studying a proposal of the section regarding the establishment of uniform inventory practices.

Representative to the Canadian Forestry Association of New Brunswick, J. A. B. Kelly, reported that 13 properties were certified as Tree Farms at two Field Days; one at Baker Brook in Madawaska County; the other at Hoyt, Sunbury County. The total number of Tree Farms certified to date is 53 (25,000 acres). A further 84 woodlots are under management. A Christmas Tree Grading Course was given at the Maritime Forest Ranger School in September. There are four 4-H Forestry Clubs in the Province and several more ready to start. The Forest Extension Service has prepared a manual and training program for these clubs.

Over 20,000 pieces of forestry literature have been distributed to school children and interested adults this year.

John P. Francis

\section{SAGUENAY}

The annual meeting of the Saguenay Section was held at Chicoutimi on Saturday, 15th October 1960.

Although the date had been carefully chosen, it developed that we were competing with several other attractions on that particular day. Nevertheless, attendance was quite good. Among those present was Mr. J. J. E. Dosne, Secretary-Manager of the C.I.F.

The morning was devoted to business. The most important item was the installation of the new Section Council.

Mr. Dosne addressed the meeting, and mentioned that he was somewhat disappointed by the fact that so few of the members of the Saguenay Section had signified their intention of attending the Joint Forestry Convention in Quebec.

However, now that the convention has passed, we are happy to be able to report that the Saguenay Section was well represented.

The afternoon session was reserved for a panel discussion on Aspects of Public Relations. The panelists were: Mr. Aime Gagne, Director of Information of the Alcan Group of Companies in the Saguenay District; Mr. J. M. Dechene, Manager, Public Relations, Canadian International Paper Company, Montreal; Mr. J. J. Beaudet, of the Public Relations Service of the Bell Telephone Company.

The sincere thanks of all the members are extended to these gentlemen, who so generously gave of their own time and efforts to make this panel both interesting and informative.

Like the panel on Access Roads' held at a previous meeting, this panel 
gave those present much food for thought. It is to be hoped that this type of discussion will be included in the program of future meetings.

A feature of these activities was the excellent publicity accorded by the local press. For this we give full credit to Mr. Andre Fortin, Chairman of the Section Public Relations Committee.

Mr. and Mrs. Bill McBride repeated their thoughtful gesture of last year, in offering their hospitality to all attending the meeting.

The day was wound-up with the emphasis on social activities at a supper and dance.

D. B. MuNN

\section{QUEBEC}

The major activity of the Quebec Section for the year 1960 culminated in the Annual Meeting of the C.I.F. in Quebec City, October 24 to 28. As predicted, it established an attendance record, and we believe was an outstanding success both from the technical and social standpoints. The credit belongs almost wholly to our chairman, Dr. Paul Lachance, and his very hard-working and enthusiastic annual meeting committees.

A section meeting was held at Berthierville on September 30. Following a brief business session, the members were given a very complete tour of the excellent facilities at this provincial nursery.

W. D. BENNETT

\section{OtTaWa Valley}

The Ottawa Valley Section began its 1960-61 season's activities with a meeting on November 17, featuring as guest speaker Dr. W. Gallay, Director of Research for The E. B. Eddy Company, Hull, P.Q. His topic was Some research problems in pulp and paper. Dr. Gallay, who obviously possesses an intimate knowledge of his subject, also has the eminent capacity of making a highly technical topic of this kind extremely interesting. The importance of this subject to Foresters is very significant. Those in attendance, a record turnout of over 80, gained a greater understanding of the technical problems of paper production, which in turn helped give perspective to basic forestry problems in growing trees.

The E. B. Eddy Company kindly acted as host for this meeting, which began with cocktails and included a Smorgasbord dinner.

Leo Sayn-Wittgenstein reported on the Joint Meeting of the New York Section of the Society of American Foresters and the Ottawa Valley Section, held in Massena, N.Y., September 15th and 16th. Although the turnout of Canadian foresters was disappointingly low, those attending found the meeting extremely interesting. The theme was Multiple land use which centered around the recreational facilities provided by the St. Lawrence Seaway Parks in the area. In addition to Leo, the Chairman, Rae Grinnell and approximately a dozen other O.V.S. members attended.

W. W. CALVERT 


\section{SOUTHERN ONTARIO}

The Annual Meeting of this Section was held on April 12, 1960. The highlight of the meeting was a most interesting talk by Dr. C. H. Doug Clarke, Assistant Chief of the Fish and Wildlife Branch, Ontario Department of Lands and Forests, on the wildlife of early southern Ontario forests.

Dr. Clarke cited several examples of animals which were very common well into the 1800 's, such as elk, passenger pigeons, wild turkeys, moose and cougars.

An interesting point is the evidence that southern Ontario was not formerly completely covered with forest, but that there were many areas of grassland. Some of these areas, and many sandy areas which later became pineries, were farmed by the Indians as early as 2,000 years ago when corn was first cultivated in southern Ontario. Although there is no evidence that the American bison existed in southern Ontario, it was a characteristic animal in adjacent parts of the U.S.A. The Detroit River has been a natural barrier for the movement of land animals because it does not freeze.

Removal of most of the forest by the white man has brought about declines in, or even extinction of, certain species of wildlife, but has aided other species. Climatic changes have also had some influence.

The first meeting of the 1960-61 season was held on October 11. Dal Hall, Chairman of the Education Committee, reported on the three-day Career Exposition sponsored by the Galt Y's Men's Club for high school students in the Galt and surrounding area. The manned booth set up by the Southern Ontario Section, one of 34 career booths, was visited by students from 20 high schools. The Exposition was open to the public each evening and was very well attended.

The speaker of the evening, Mr. Les McKimmie, Vice-President of the J. B. Morgan Lumber Company, gave an interesting and humorous talk on I.umber Associations in Canada. He also included a discussion of the purpose of National Forest Products Week, of which he is national chairman.

F. M. Buckingham

\section{Central Ontario}

The Central Ontario Section held a summer meeting at Chapleau on July 22nd and 23rd, with jack pine management the theme for the occasion. A field trip occupied the afternoon of the $22 \mathrm{nd}$ and was attended by eighteen Section members, plus a delegation of eleven foresters from Michigan. This tour was ably conducted by Cam Stevens of the Department of Lands \& Forests, Chapleau.

Features of the field trip included a visit to a tree girdling and chemical treatment project involving 40,000 cords. This is being carried out by Huron Forest Products for the purpose of debarking spruce prior to cutting. H. E. P. Wilson and Ken Allebone were on hand to describe the program.

Also seen was an experimental strip-cut undertaken by the Ontario Department of Lands \& Forests; plus scarification work done by bulldozers using an Imset scarifier and a tool bar attachment.

A stop was made to examine the damage done to jack pine stands by a 
heavy, freezing rain in early May. From there the group moved to another area where it was shown the results of aerial spraying designed to release planted pine from brush competition. The field trip concluded with a look at a substantial area burned in 1948 which has reproduced to jack pine at a rate of 22,000 trees per acre. Thinning is being carried out in these stands based on $6^{\prime} \times 6^{\prime}$ spacing.

Accommodation was provided at the Lands \& Forests' Racine Lake Camp. Following an excellent supper there was a business meeting chaired by the Section's vice-chairman Harry Graham. Business items dealt with included the following:

Details concerning a regional meeting on regeneration were considered.

There was discussion concerning the Section's resolution on forest management in Indian Reserves.

Harry Graham was given the job of editing the Section newsletter.

The DVA Forestry Course and its promotion received attention.

A questionnaire submitted by G. Morrison of the C.I.F. Forest Managenent Committee was dealt with.

Plans were considered for a joint meeting with the Michigan-Wisconsin Section of the S.A.F.

Following the business session American and Canadian foresters exchanged information concerning their respective jobs and organizations. John Morawski of the Ontario Department of Lands \& Forests gave a talk on jack pine regeneration. Oliver Korpela of the Island Lake Lumber Company spoke on the marketing of jack pine sawlog products. Wm. Foreman, of Lands \& Forests, outlined the intensive management program being undertaken in the Racine Lake area. And Wm. Beaufait of Michigan Tech. described his experiences with prescribed burns in regenerating jack pine.

A vote of thanks was extended to Mr. Keddie and his Lands \& Forests staff for their contribution in making the Chapleau meeting a very real success. The program concluded with many making visits to the Labrenière mill on Racine Lake and the Lands \& Forests tree nursery at Chapleau.

G. R. MORRISON

\section{NORTHWESTERN ONTARIO}

A meeting of the section was held in the library of the Lakehead College on Wednesday evening, October 17th, 1960. Mr. Henry Clepper, Executive Secretary of the S. A. F., and Dean Frank H. Kaufart of the University of Minnesota, School of Forestry, were present and discussed with us some of the tentative plans for the joint annual meeting to be held in Minneapolis next year.

Following this main item of business the members present enjoyed a very frank and animated discussion on numerous subjects of interest to foresters.

On Friday, November 4th, a meeting of the section was held at Club 17. Following the dinner Messrs. Ken Hearnden and Mark Cressman presented a full report on the Annual meeting at Quebec City. Quebec Section is certainly to be commended for their effort in putting on a very successful annual meeting which seven of our members were fortunate enough to attend. 
This section together with the other Ontario sections of the C. I. F. has appointed liaison representatives to work with the Ontario Professional Foresters' Association in dealing with items of mutual interest in the Provincial field. It should be an important step for both foresters and forestry in Ontario. Personalia

Mr. J. D. Brophy has been transferred from Manitoulin Island to Heron Bay by the Ontario Paper Company recently. Mr. Hollis Routledge has left the Ontario Paper Company at Heron Bay and moved to Nova Scotia. Mr. D. E. Story arrived from Pembroke, Ontario in October to take over the duties of Assistant Divisional Forester with the Abitibi Power and Paper Co., Port Arthur, Ontario. We are happy to report that Mr. F. L. Stevens has been appointed Manager, Lakehead Woodlands, of the Abitibi Power and Paper Company. Mr. Don Richards of the Marathon Corporation, Stevens, Ontario, is taking advanced studies in business administration at the University of Western Ontario. Mr. G. E. Currey of the Kimberly-Clark Pulp and Paper Co. at Longlac has returned to the University of Toronto for his second year's work toward a master's degree in forest management. Mr. Robert Briggs has been transferred from the Spruce Falls Power and Paper Co. at Kapuskasing to the Longlac staff of the Kimberly-Clark Pulp and Paper Co.

R. S. HYSLOP

LAKE OF THE WOODS

A joint meeting of the Lake of the Woods Section and the Manitoba Section was held at Falcon Lake, Manitoba on September 24. Sixteen members of the Lake of the Woods Section attended.

The group were taken on a tour of part of the Whiteshell Forest Reserve. Points of interest observed on the tour were the three beaches on Falcon Lake, the golf course and shopping centre at Falcon Beach, the summer cottage development around Falcon Lake, the fish hatchery at West Hawk Lake and the tree nursery at Hadashville. The entire development of this tourist resort area has been under the direction of the Manitoba Forest Service.

A dinner was enjoyed by the group at the El'nor Motel. Chairman for the evening was S. C. Howe of the Manitoba Section and guest speaker was G. W. Malaher, director of Game and Fisheries for the Province of Manitoba.

Mr. Malaher showed a most interesting movie on the tagging of caribou in northern Manitoba. He explained that this tagging experiment was necessary in order to obtain information on the migrations of caribou herds in the north. The caribou population has decreased rapidly in the past years and because the Eskimos and Indians rely on the caribou as their chief supply of food, the problem has become very serious.

In 1959 the Game Branch tagged 112 animals and in 1960, 226. The tagging was done while the caribou swam across lakes and the movie shots of this were spectacular. Mr. Malaher noted that three tags were recovered this year and one of the caribou travelled 350 miles from the place of tagging in 1959.

This was the first joint meeting between the Manitoba and the Lake of the Woods Sections of the C.I.F. and many members expressed a wish to hold another such meeting in the future with Lake of the Woods Section as hosts. 
The Lake of the Woods Section held a meeting in Dryden on November 19.

The fifteen members who attended were taken on a tour of the Mechanical Logging Operations in the Dryden Paper Company Limited North Division timber limit. A Garrett Tree Farmer and four Timberland Skidders were cbserved skidding tree-length pulpwood to landings where the trees were bucked up into eight foot lengths and piled by a TD 5 Drott.

H. A. Coles was chairman of the business meeting. A nomination committee and a program committee were appointed and the program committee was instructed to select a topic concerning forest access roads. Members of this committee are: R. Boultbee, H. J. Henry, and P. J. Harrison.

With regard to a request that this section solicit advertising in The Forestry Chronicle, the members were opposed to courtesy advertising and the Secretarytreasurer, D. J. Vance, intended to write The Forestry Chronicle to get the most recent opinions on this matter.

W. F. BEATTY

\section{MaNitoBA}

A joint meeting of the Manitoba and Lake of the Woods Sections was held at Falcon Lake in Manitoba's Whiteshell Forest on September 24. Eighteen members from the Manitoba Section and fourteen from Ontario attended the meeting.

Tours of the Whiteshell and the Forest Nursery at Hadashville were made under the supervision of H. P. Laws, after a short speech of welcome from S. C. Howe. Mr. G. W. Malaher, Director of Game, for Manitoba, was guest speaker at a supper which followed cocktails at the El'nor Motel, Falcon Lake. Mr. Malaher spoke on the tagging of caribou. Biologists are thus able to study the habits of this migratory animal which is so important in the north. The talk was illustrated with a film.

Mr. G. H. D. Bedell of Ottawa, and Mr. C. C. Thomson of Winnipeg, together with other members of the Forest Research Division were able to tour the forested areas of Western Manitoba the last week in September. They were shown most phases of woods operations and particular emphasis was placed on white spruce regeneration on cut-overs, in open areas, and on scarified-after-cutting operations. This tour had been a long time in the planning stage. Mr. Bedell had instigated the first management plans for parts of the district in the thirties. He was impressed with the volumes of timber still cut, the size of the spruce and particularly the colouring of the native hardwoods.

A large turnout of professional foresters and friends gathered in Winnipeg on September 30, to say farewell to C. B. Gill, who terminated his services with the Manitoba Forest Service after many years. His interest in the forests of his native province will bring him back to Head Office and to the districts, we hope, on many visits in the years to come.

Mr. J. G. Somers, Provincial Forester, attended the World Forestry Conference in Seattle. W. C. (Bill) McLean, brought back an accent from the C.I.F. Convention in Quebec.

C. K. SMITH 


\section{SASKATCHEWAN}

The first fall meeting of the Saskatchewan Section, Canadian Institute of Forestry was held in the Board Room of the Provincial Government Building in Prince Albert on the evening of September 30th, 1960.

The main purpose of the meeting was the provision of direction to the Section Representative who has been designated to attend the Joint Forestry Conference in Quebec from October 23rd to October 27th, 1960. Thus the main discussion centred around the various resolutions which had been submitted for presentation at the Annual Meeting. The feelings of the Saskatchewan Section concerning these resolutions were expressed for the guidance of our Section Representative, A. O. Aschim.

Other business discussed included the matter of a joint Manitoba-Saskatchewan meeting. Although this proposal was initially brought forward a year ago, no definite action has been taken yet. It was moved that the matter be tabled until next spring since summer or early fall would be the best time for such a meeting.

At the conclusion of the business portion of the meeting, $\mathbf{H}$. Kagis gave an interesting talk dealing with some of his findings regarding Jack Pine Regeneration. He used slides effectively to illustrate his talk, and all those present were appreciative of his efforts. The meeting was adjourned at the conclusion of Mr. Kagis' presentation.

The Saskatchewan Section of the Canadian Institute of Forestry held its second meeting of the fall season in the Board Room of the Provincial Government Building in Prince Albert on November 18th, 1960, at 8:00 p.m.

The business portion of the meeting was held to a bare minimum in order that the scheduled program speakers would have adequate time for their presentations.

The first speaker was Director of Forests, W. R. Parks, who gave an illustrated talk dealing with general information aspects of the World Forestry Congress held in Seattle earlier this fall. He gave a general overall coverage of the Congress dealing, for instance, with such aspects as accommodation, delegates in attendance and travel to and from the conference.

H. Kagis then gave a talk on the theme of the Congress-Multiple Use of Forest Land-with special reference to the talk by Dr. Egon Glaesinger, the Director of Forestry and Forest Products Division with F.A.O. Mr. Kagis also showed pictures covering the tree planting ceremonies at the Congress in which trees were planted by delegates from each of the countries represented.

C. L. Kirby then covered the Forest Inventory aspect of talks given at the Congress. At the conclusion of his talk the meeting recessed while the members enjoyed a coffee break.

On the resumption of the meeting the Section Representative to the Joint Forestry Conference in Quebec, A. O. Aschim, gave his impressions and report on proceedings at the conference.

Prior to this meeting. Mr. Aschim had circulated copies of conference papers among the C.I.F. members. In this way the members gained some idea 
of proceedings at the conference before the Section meeting and were thus in a better position to express opinions or ask meaningful questions.

Mr. Aschim gave good coverage of proceedings at the conference and provided answers to questions which were posed by some of the Section members.

The meeting adjourned at the conclusion of Mr. Aschim's presentation. Personalia

Doug Golding who has been on a year's leave of absence while attending Purdue University recently resumed his duties with the Inventory Division. Doug took postgraduate work in forest inventory.

Forester John McLellan, a graduate of Edinburgh University, joined the Management Division of the Forestry Branch in July. John, a native of Scotland, had previously worked in British Columbia and is looking forward to his first winter of deep snow and sub-zero temperatures.

Another new Forester with the Department, Al Aldred, has joined the ranks of the Inventory Division. Al is a graduate of U.B.C. and he, too, was working in British Columbia before coming here.

Forester Alex Dickson, formerly Extension Forester with the Department of Natural Resources, has been appointed Director of the Natural Resources. Training School at Prince Albert. Fourteen students are currently attending the school for the seven-month classroom portion of their training.

Regional Forester Carl Burton of Meadow Lake Region has left on a year's leave of absence to study at Michigan State University. While away Carl will be studying recreation with particular reference to forest recreation.

\section{Rocky MOUNTAIN}

M. C. Millar

The Rocky Mountain Section held its fall meeting in Rocky Mountain House, Alberta, on September 23, 24 and 25. Accommodations for the gathering were ably organized by George Ontkean, Alberta Forest Service, Rocky Mountain House. This meeting stressed the social aspects of the Section's activities and contrasts with the other two Section meetings of the year. In these two meetings a forestry theme is selected and members concentrate on various aspects of the topic under discussion.

The meeting opened on Friday evening September 23, with registration and a reception for members and their wives. The gathering continued with a general business meeting on Saturday morning. An interesting feature of this session was a discussion of the status of the lumber industry in the Province in the light of the current depressed condition of the lumber market. After a luncheon, the members went on a tour of the Federal Forestry Branch's pine regeneration and thinning plots at nearby Strachan, Alberta. This tour was conducted by Mike Drinkwater, Federal Forestry Branch, Calgary, and Gus Loman, Forest Biology Laboratory, Calgary, Alberta. Gus Loman explained the nature of the pathological and entomological studies on the area. Mike Drinkwater conducted the group through plots where various methods of cutting had been experimented with in order to secure adequate forest regeneration. He also illustrated the benefits of soil scarification in obtaining satisfactory regeneration. 
The evening banquet had Mr. Henry Stelfox, a pioneer farmer and rancher of the region, as guest speaker. Mr. Stelfox spoke on the highlights of the history of Rocky Mountain House and its surrounding district. He also described his early fur trading activities with the local Indians.

On Sunday the meeting broke-up and the Section members returned to their homes.

\section{OKANAGAN}

R. F. FYTCHE

The elected Executive for the 1960-61 season is: Chairman N. A. McRae, Vice-Chairman F. Stinsen, Councillors N. V. Mason, A. J. Strother and B. Ford. B. Ford has since resigned when he joined the staff of the B.C. Lumber Manufacturers Association as Overseas Field Representative. The following appointments were made: Secretary-Treasurer O. J. Andersen, Membership committee F. Stinsen and Editorial Representative and Education Committee H. C. R. Gavin.

W. W. (Pat) Stevens died at the Royal Inland Hospital in Kamloops on November 3rd, 1960. He was a well-known Forest Consultant in the Kamloops region and is sadly missed by the members of the Section.

At the final meeting of the 1959-60 season, held on April 29th, 1960, R. Spilsbury, Forester-in-charge of the Research Division of the B.C. Forest Service, delivered an interesting and well illustrated account of Forestry Practices in Sweden. The lively discussion which followed reflected the keen interest in the subject.

The opening meeting of the new season concerned the timely topic of the use of aircraft, particularly water bombers, in fire protection. Art Sellers and Peter Dick of Skyway Air Services, outlined the experience of the company during the past summer. The company's film, The Mud-slingers, showed the effects which could be expected from different types of aircraft. Proposals were made to increase the effectiveness through preparedness and through the development of special techniques and equipment.

H. C. R. Gavin

\section{Cariboo}

The Cariboo Section started the 1960 - 61 season with a bang. We have already held one party and two meetings with a promise of many more exciting events for the latter part of the year.

To open the season a get acquainted party was held at Phil and Barbara Rodman's, who very kindly lent their house for the festivities. Members and wives thoroughly enjoyed themselves and while doubtless subjects other than forestry were discussed, numerous conversations using logging terms were noted!

The second meeting of the $1960-61$ season was held on October 14th, 1960 at Smithers, B.C. The 15 members of the Prince George contingent were outnumbered by the Prince Rupert and Terrace groups, who it is reported arrived in droves.

After a brief business meeting, during which Mr. D. Kent, our membership committee chairman, exhorted everyone to pay their dues, Mr. Frank Maher, the guest speaker for the evening, was introduced by A. L. Dixon, 
District Forester of the Prince George Forest District. Mr. Maher is the Division Fisheries Biologist with headquarters in Vancouver. He gave a very factual talk on his field of endeavour and discussed at some length the need of more co-operation between the field of forestry and his own, especially with regard to stream pollution. His interesting talk was capped by a lively question and answer period.

After the adjournment of the meeting, members gathered in the Bulkley Hotel and at the Hilltop Motel, where further discussions, not necessarily on the subject of forestry, were carried on at some length.

The third meeting was held on November 18th, 1960. After a business session, the members listened with great attentiveness to our local delegate Phil Bodman reporting on his trip to the National Convention, and the discussions which were held at Quebec. Coffee and doughnuts were served after the adjournment of this interesting session.

R. Clifford

VANCOUVER ISLAND

With the World Forestry Congress on our doorstep, it has been possible to start the 1960-61 Institute year with a rush. Dr. Syrach Larsen was an outstanding guest speaker at the first meeting held in Duncan on August 26th. Over 70 members and guests heard Dr. Larsen's interesting and inspiring address on forest genetics. Jake Holm, a former student of Dr. Larsen, introduced the speaker, and Dr. Allan Orr-Ewing expressed the appreciation of those present.

A post-Conference Tour of part of British Columbia provided further opportunity for International fellowship. Twenty Section members and their families welcomed the tour delegates as they arrived in Victoria by various routes on Sunday, September $11 \mathrm{th}$. Some forty-two delegates representing seventeen countries were entertained on tours, teas, dinners and evening receptions.

The next day the delegates were the guests of the Vancouver Island Section at a luncheon served at the Duncan Nursery. Including tour guides, C.I.F. members, etc., some 77 people enjoyed a very tasty meal. Chairman Jim Kinghorn welcomed the guests on behalf of the C.I.F. and Dr. Cabral of Brazil and Professor Mobbs, Head of Department of Forestry, University College of North Wales, expressed the appreciation of the guests. Unfortunately the tight tour schedule did not permit too much time for informal discussions.

The annual Section Field Trip this year was a visit to the Caycuse Camp of British Columbia Forest Products. Highlights of the trip were a visit to one of the oldest industrial plantations on the Island and a re-examination of the 1956 tractor-scarification-plus-planting in the Wilson Creek drainage where survival and growth are indeed gratifying. The 1960 extension of this project indicates that planting of 500 trees per acre in these heavy Salmonberry areas can be done for under $\$ 20.00$ per acre even with very heavy debris. The group lunched in the timber at McLure Lake where the largest Wyssen crane yet to be built is to operate. Logs will be dumped into the lake. After lunch, hot planting in a 1960 slash burn and a skidder operation were visited.

A. H. BAMFORD 